\title{
The Behavior of Information Usage through Newspaper By Moslem Leaders in Medan
}

\author{
A.Thamrin, $\mathrm{SK}^{1}$ \\ ${ }^{I}$ Ph.D Student at State Islamic University of North Sumatra (UINSU), Medan \\ ${ }^{1}$ Lecturer atDa'wah Faculty, State Islamic University of North Sumatra (UINSU), Medan
}

\begin{abstract}
The information from the mass media is considered inaccurate, and some other reasons. This is more visible when it is connected to an incident which requires that the information can be quickly delivered and accepted by society. One sample case is the crane collapse at Grand Mosque during the pilgrimage in 2015 and Mina incident where many of pilgrims ran jostle that many of them fell and were trampled by other pilgrims, so many were injured and died. The number of those who died as a result of the incident was more than 1,000 people, including about 100 more pilgrims were from Indonesia.The results are the various usages of information. However there is a red thread (similarity). In other words, there is the sense or the same meaning. For example to increase knowledge, to broaden insights, to know the latest developments, to compare, to assist in solving the problems, to establish social relationships, to enhance trust, to entertain, can be delivered to the family or anyone else. Information is not to enhance and strengthen self-confidence.
\end{abstract}

Keywords: behavior; newspaper; Moslem leaders; information

\section{INTRODUCTION}

This study is taken from the assumption that Muslim leaders in the Medan City are searching and using information through newspapers in fulfilling their needs for information. They do that in relation to their existence as individuals and also their positions as Muslim leaders. As individual Muslim leaders, they are demanded to increase their knowledge, broaden their insights, and have sufficient and adequate information, not only concerning about religion but also other various aspects which are developing in society. Life in Medan City is very dynamic, pluralistic society in various aspects, especially in culture and religions. This condition has become a challenge for Muslim leaders to build and create conducive situations, so as it will create a society that is full of tolerance, mutual respect and mutual veneration.Some issues on behavior of seeking information are related to public beliefs in the information delivered by printed media, especially newspapers. For instance, it is about the truth of the information. Recently, people sometimes do not believe in the information conveyed through mass media including newspapers. There is often a negative perception in some society relates to information through the mass media, especially newspapers. The information from the mass media is considered inaccurate, and some other reasons. This is more visible when it is connected to an incident which requires that the information can be quickly delivered and accepted by society. One sample case is the crane collapse at Grand Mosque during the pilgrimage in 2015 and Mina incident where many of pilgrims ran jostle that many of them fell and were trampled by other pilgrims, so many were injured and died. The number of those who died as a result of the incident was more than 1,000 people, including about 100 more pilgrims were from Indonesia. Besides that there are the characteristics of a newspaper are sought among Islamic leaders in fulfilling their needs for information. The types of newspapers they are looking for, how to get a newspaper, time and frequency of information search through newspapers, the duration spending in searching for information in newspapers, kinds of issues and information form.

\section{METHODOLOGY}

The behavior of information usage through newspaper in this study is how the informants namely the Islamic leaders use the information obtained in searching the information through newspapers. The behavior of information usage through newspaper is a follow up action on the behavior of information searching through newspaper. Both searching behavior and using behavior are like a inter-related package. In fact, it is sometimes difficult to determine which actually the first one between information search or information usage through newspapers is. The searching is based on the usage or the usage that causes the searching. This can be said as an egg with a hen. Which is first, the egg or the hen? A common simple answer given is usually which one is first mentioned. If it is first mentioned the egg then it is the egg, on the contrary if the hen is first mentioned then it is the hen. It is also the same as the search and the usage. If the search means to search first, then if it is the usage 
is first mentioned then it is the usage. For that reason, there have been interviews towards the research informants that is the Islamic leaders.

The next details describe about the behavior of information usage through newspapers among Islamic leaders in Medan City. Based on the results of interviews with Prof. Dr. H. LahmuddinLubis, M.Ed who stated that "The information usage through newspapers is to increase the knowledge, broaden the insights, to follow the development, to compare, and to entertain. In this case the entertainment is news or sports information".

Someone's knowledge will be improving and the insight will be wider by accessing the information through various sources including newspapers by reading them. Reading is a fundamental human activity in an effort to acquire and to increase their knowledge. Reading makes many people become aware of various things. By reading, people will be smart. Reading will make people richer with knowledge. If people want to keep young, then the reading culture should be embedded early.In this context there is a term bagaikankatakdalamtempurung (Like a frog in the coconut shell). It means that people who feel great have big heads with their abilities. In fact they do not have much or even nothing. They just think themselves are great, but not actually great. If they are indeed great, it is just for local or neighborhood (shell). There is another sky above the sky. People should not feel arrogant. People sometimes dream in the midday. In fact, someone should be great in a real sense, that suitable with his skill. For that reason, being great must be together with the increase of the vast knowledge and insight.The meaning of comparison is comparing the knowledge that someone has with the knowledge he acquires through newspapers. People can measure themselves relates to their knowledge positions. If they have got or have known it, it means it can strengthen, but if they have not got any or they have not known, it means it can add. That is the advantage of the information searching through newspapers. Similarly, many other things can be used as comparison. But the most important thing is the comparison between the old knowledge to the new one. Due to the information through printed media newspapers generally delivers new information. And thus the various information that previously have got, their development can always be up date and kept sustainable.The intention to know the developments in this case is something a must and surrealistic because it is very important. By knowing the development, there are a lot of advantages to achieve. For example, things relate to the sale of products or things. The seller can adjust the price to the market price. Let say he wants to sell the car, so the price of the car is based on the market price. So the seller will not lose. It is also the same as other case, for example an endemic in a country. By knowing the ongoing developments, then the destination country can be changed to other more secure country, or to be postponed. Likewise, the developments related to the climate. If there is a strong wind and high wave, then any sea activity for a living must be cancelled until the situation is conducive. Otherwise life can be in danger. In fact life is a priceless treasure. There is also for entertainment but very limited. There has been a trend from sports section in the newspaper. For those who like sport, then sports section may entertain them. That is why many people access a newspaper on a page that has a lot of information about the sport, for example the European soccer Cup. Each of people has his favorites. Some prefer Germany, France, Britain, Belgium, Spain, Portugal, and other countries. However it seems that Germany is expected to be able to maintain its position in the 2016 European Cup. But in reality Germany was defeated, and Spain came out as the 2016 European Cup champion.Based on the interview with Prof. Dr. H. Asmuni, M.Ag who stated, "The information usage in newspapers is to increase knowledge, to broaden insight, to help in solving the problem, to establish the social relationships, and to increase the self-confidence and self-esteem." This statement explains that besides increasing knowledge and broadens insights; the information usage is to assist in solving problems, to establish social relationships, and to increase self-confidence and self-esteem.Assisting to solve the problem means that the information obtained through newspapers can be used to resolve the problems that the people have. If it cannot solve the problems, at least it can help in resolving the problem. For example, information about fasting obtained through newspapers can be used to help in resolving the problems relates to the beginning of Ramadan, and some other problems. Another example is information about a certain area which has become a tourist destination. It can help any tourists in determining their tourism destinations to be visited when the holiday season comes.Establishing social relationships is that the information through newspapers can be used in establishing social relationships, or assisting in establishing social relationships because in social relationship, information is needed. Without information, there will be material shortages in communicating. Information can help in making the communication runs smoothly. People who have many materials will be easier to communicate. The relationship will be more intimate and so forth. Therefore, the behavior of information searching in newspapers is an issue that must be done.The improvement of self-confidence and self-esteem is an attitude as a result of information obtained through newspapers. This means that when people have enough information, then the self-confidence and self-esteem will increase. Self-confidence is an attitude which appears more confident. Self-esteem is the result from self-confidence. Based on the interview with Dr. Maratua H. Simanjuntak who said that, "The information usage in newspapers is to increase the available information, to follow the latest developments, and to increase the self-confidence." This statement clarifies that the information usage is for the strengthening of obtained information, or in other words to more strengthen the obtained 
information before.Based on the interview with Prof. Dr. H. Syafaruddin, M.Pd who stated, "The information usage in the newspapers is to add to the knowledge which has obtained, to know the events happen today, to know the opportunities of science and organizational, as well as to know the various opinions." This statement explains that the information usage is to strengthen the existing and obtained information, so that the information usage for progress is a necessity and inevitability.Based on the interview with Dr. H. Ahmad ZuhriLc, MA who states that "The use of information in the newspapers is to broaden insights, to increase knowledge, to know the latest developments, to assist in solving the problem, to establish social relationships, and to entertain." This means that there are many uses of information obtained through the newspaper. Besides those mentioned above, of course, the uses are for any other purposes.Based on the interview with Dr. H. Muhammad Sofyan, Lc, MA states that, "The information usages through newspapers are to help in solving problems, to add and to strengthen the ideas, and social relationships."Among the usages mentioned above which help in solving the problems, Tax Amnesty (taxation) is the example. Through the newspapers, someone can obtain information about the development of tax amnesty. For a lecturer of economics, this information will be very helpful as a substance or material in the lecture.Based on the interview with Dr. H. Arifinsyah, M.Ag who stated that, "The information usage through newspapers is to help in solving the problems and to establish social relationships, but the information is not to improve and strengthen the self-confidence and self-esteem because the newspaper's information is not necessarily accurate and true". This statement is understandable, because indeed the information through newspapers sometimes not is inaccurate, so it is necessary to check the information. This is a manifestation of vigilance form against the information. Because the incorrect and inaccurate information can hurt, harm, or even to mislead. But this statement does not fully contain the accurate thing. Information can certainly improve the self-confidence.Based on the interview with Dr. H. AzharSitompul, MA stated that "The information usage in the newspapers is to increase knowledge, to strengthen selfconfidence, and to establish the social relationships." ${ }^{1}$ As social human beings, man cannot escape from the surrounding environment. In other words, humans must interact with other human beings. In the interaction, human requires the presence of sufficient material or information that can be used for sharing or exchanging information about various things, such as the information about religion, business information, information about politics, and so on.Based on the interview with Dr. H. ZainalArifin, MA stated that, "The information usage through the newspapers is to increase knowledge as preaching material, to establish social relationships, and to increase the self- confidence. ${ }^{2}$ The preaching activity is an activity that should be encouraged or backed up by their sufficient knowledge or information as preaching materials to enrich the materials. If the preaching materials are sufficient, the preaching activities run smoothly as expected. When the preaching is performed with the less materials, then the preacher will finish his preaching activities with less of appreciation or respect. Therefore, information through newspapers is important as an additional material for preaching material to be conveyed to the audience $\left(\operatorname{mad}^{\prime} u\right)$. Based on the interview with Dr. H. Ardiansyah, MA stated that, "The information usage through newspapers is to increase knowledge and to help in solving the problem". ${ }^{3}$ This has been stated previously that many information usages obtained through newspapers, including in solving problems. Islamic leaders are people who are always close to the society. So that they often ask to the Islamic leaders. For example questions about various developments problems around the society, including economic and political, and of course about religion. This surely requires Islamic leaders to find a lot of information, not only religion but also others things.Based on the interview with H. FachrurrozyPulungan, SE stated that, "The information usage through the newspaper to find out current developments on various matters and can be delivered to the family or anyone else". ${ }^{4}$ This statement explains that the information usage through newspapers that is besides to increase the knowledge for them, it also delivers to the immediate environment, either family, neighbor neighbors, or the community that can be reached. Thus, the information creates useful effect for the society much widely. This can encourage people to be more aware and responsive to the information. The information is considered as important and strategic because the current situation and condition is in a period called the 'information era'. People should know the importance of information. The following discussions relate to the behavior of information usage through newspapers on Muslim leaders in Medan City. As stated in the study's findings that the behavior of information usage in newspapers is part of human behavior. The behavior

${ }^{1}$ AzharSitompul, Vice Dean of Students' Affairs, Alumni danKerjasamaFakultasIlmuSosial (FIS) UIN Sumatera Utara, The interview held in Campus II UIN Sumatera Utara Medan, on 18 April 2016.

${ }^{2}$ ZainalArifin, Lecturer of FakultasDakwahdanKomunikasi (FDK) UIN Sumatera Utara, The interview held in Campus II UIN Sumatera Utara Medan, on 17 May 2016.

${ }^{3}$ Ardiansyah, General Secreatary of MajelisUlama Indonesia (MUI) Sumatera Utara, The interview was held in MajelisUlama Indonesia Office in JalanSutomo Medan, on 8 June 2016.

${ }^{4}$ FahrurrozyPulungan, Teacher, the interview was held in JalanBelat Medan, on 20 May 2016. 
of information usage through newspapers or human action is the act of using information obtained through newspapers. The behavior of the information usage in newspapers is the follow up on the searching behavior information through newspapers. The discussion focuses on how the information usage or what is the information usage for that has been obtained through newspapers. The study results are as described in the study's findings that there are various information usages on Muslim leaders in Medan City. Nevertheless, there is a red thread (similarity) view of the substance that the information usage on Muslim leaders is to meet the various requirements.It is seen clearly as in the following: to increase knowledge, to broaden the insight, to know the latest developments, to compare, to assist in solving the problem, to establish social relationships, to increase self-confidence/self-esteem, to know the various opportunities the development of science and organization, to know the various opinions, to entertain, to strengthen the idea, to add knowledge as preaching material, to determine the development about many things and can be delivered to the family or anyone else.

\section{DISCUSSION}

The information usage through newspapers on Islamic leaders has been revealed. In this case there is an expression that looks different that is the information is not to improve and to strengthen self-confidence/selfesteem because the information from newspaper is not necessarily accurate and true. In addition, there is also an interesting phrase which says that the information usage in newspapers is as material for preaching. This means that the information obtained through the newspaper can be used or contributed as preaching materials. The phrase explains that the information usage in newspapers besides to increase knowledge for ourselves, it also to be submitted to the immediate environment, either to the family, neighbors, or the community. Thus, the information may affect the benefits to people much widely. So this can encourage the public awareness towards the information. This is much familiar with information literacy because the current situation is in the middle of the information era. People should realize on the importance of information. Thus, people must be more responsive to information, especially the important and strategic information for life and future.The information usage through newspapers as mentioned in the results of study above seems to fit with the position of informants as Islamic leaders. With their status as Islamic leaders of course they need information that can be used to meet various purposes, such as that has been mentioned above to increase knowledge, to broaden insight, to assist in solving problems, and to establish social relationships.The usage terms mentioned in the theoretical study comes from the word "usage" means; 1) profit, 2) function, 3) goodness. The usage is a process or way of using something. Thus, the meaning of the information usage through newspapers can be interpreted as to avail or function of information through newspapers for Islamic leaders. The behavior and activity of human in Islam must correspond with the values in the teachings of Islam. They include the behavior and activity of human in searching and using the information through newspapers. The usage in the sense of utility or the function of information through newspapers should be in accordance with the teachings of Islam. The behavior of searching and using information is an activity associated with the searching and the adding knowledge. In Islam, studying and increasing knowledge is an obligation. Charity or worship must be based on the knowledge because if it is not based on the knowledge then charity is rejected. How important studying is. The advantages and functions of information through newspapers for Islamic religious leaders basically must be used to add the faith and piety in order the devotion to Allah SWT.The discussion related to the behavior of information usage through newspapers as described thoroughly above, if it refers to or is based on the theory of uses and gratifications and the uses and effect as an analysis key, the behavior of the information usage through newspapers in fulfilling the information needs on the Islamic leaders are in accordance with the concepts found in both theories. In the uses and gratifications theory, it mentions that the use of mass media is to fulfill the certain purposes. In the context of this study it is the mass media, namely newspapers. The behavior of information usage through newspapers on Muslim leaders is to fulfill various purposes, such as to add and to enrich knowledge as well as to broaden insights. Then, the theory also suggests that individuals or public society choose the type of media and media content that can meet their various needs. This means that Islamic leaders choose the type of newspapers and the newspaper content. In this case, they chose Waspada, Analisa, andRepublika. Similarly, the media content they choose are politic, economic, social, cultural, and religious issues. And so is according to the theory of uses and effects that says the use of the mass media (newspapers) can give an effect on the individual that is the Islamic leaders. In this case it is the effect of media content (newspapers).Based on the above description, the theory of uses and gratifications and the theory of uses and effects that are used, are relevant and appropriate to the study. In these theories the emphasis is also on Islamic leaders who use the information in newspapers to meet their needs.

\section{CONCLUSION}

The usage is a process or how to use something. Another meaning of information usage through newspapers can be defined as the advantage or function of information through newspapers. The results are the various usages of information. However there is a red thread (similarity). In other words, there is the sense or 
the same meaning. For example to increase knowledge, to broaden insights, to know the latest developments, to compare, to assist in solving the problems, to establish social relationships, to enhance trust, to entertain, can be delivered to the family or anyone else. Information is not to enhance and strengthen self-confidence, because information from the newspaper is not necessarily accurate and true. In addition, there is an interesting phrase which says that the information usage through newspapers used as preaching materials. This means that the information obtained through the newspaper can be used or contributed in preaching activity.

\section{REFERENCES}

[1] AlqurandanTerjemahannya, Kementerian Agama RI.Al- Antaqi, Wajihuddin. MisiEtisAlquran. Yogyakarta: Titian Ilahi Press, 2000.

[2] Albarracin, Dolores, Blair T. Johnson \& Mark P.Zanna, The Handbook of Attitude, Routledge, 2005.

[3] Alwi, Hasan. KamusBesarBahasa Indonesia. Jakarta: BalaiPustaka, 2001.Amir, Mafri.EtikaKomunikasiMasaDalamPandangan Islam. Jakarta: logos, 1999.

[4] Arifin, Anwar. KomunikasisebuahPengantarRingkas. Jakarta: Rajawali, 2002).

[5] . DakwahKontemporer: StudiKomunikasi. Yogyakarta: GrahaIlmu, 2011.

[6] Arikunto, Suharsini. ProsedurPenelitianSuatuPendekatanPraktek. Jakarta: RinekaCipta, 1992.

[7] Assegaf, Djafar. JurnalistikMasaKiniPengantarkePraktekKewartawanan. Jakarta: Ghalia Indonesia, 2001.

[8] Atherton, Pauline. Handbook for Information System and Service. Paris: Unesco, 1977.

[9] Azwar S, SikapManusia; TeoridanPengukurannya. Jakarta: Universitas Indonesia, 2003.

[10] Basuki, Sulistyo (dkk). PerpustakaandanInformasiKonteksBudaya. Depok: FIB UI, 1993.

[11] Barelson, "What Missing the Newspaper Means," dalam Schramm The Process and Effect of Mass Communication, Urbana: University of Illinois, 1954.

[12] Bouazza, Abdelmajed. "Information User Studies,"dalam Allen Kent (Editor) Encyclopedia of Library and Information Science. New York: Marcel Dekker, 1989.

[13] Bungin, Burhan. Analisa Data PenelitianKualitatif. Jakarta: Raja Grapindo, 2003.

[14] Daryanto.KamusBahasa Indonesia Lengkap. Surabaya: Apollo, t.t.

[15] Depdikbud.KamusBesarBahasa Indonesia. Jakarta: BalaiPustaka, 1990.

[16] Devito, Joseph A. KomunikasiAntarManusia. Jakarta: Professional Books, 1997.

[17] Dharmesta (dkk).ManajemenPemasaranPerilakuKonsumen. Yogyakarta: BPFE, 2012.

[18] Echol, JhonM(et al). KamusInggris Indonesia. Jakarta: Gramedia, 1996.

[19] Edward, Evan G. Developing Library and Information. Littleton: Library, 1987.

[20] Effendy, Onong U. IlmuKomunikasi: TeoridanPraktek. Bandung: RemajaRosdakarya, 1994.

[21]_. DinamikaKomunikasi. Bandung: RemajaRosdakarya, 1992.

[22] . Teori, EtikadanFilsafatKomunikasi. Bandung: AdityaBakti, 1993.

[23] Eysenk, HJ (ed). Ecyclopedia of Psicology.New York: Herder and Herder, 1972.

[24] Faisal, Sanafiah. PenelitianKualitatif. Malang: YA3, 1990.

[25] Fatterman, Using Qualitative Methods in Educational Research. San Fransisco: Jossey Bass Inc. Publisher, 1991.

[26] Gerungan, W.A. PsikologiSosial. Bandung: RefikaAditama, 2004.

[27] Gurevitch, Katz, E.M, Gurevitch, M. \& Hass, H. 1973.

[28] On the Use ot Mass Media for Important Things. American Sosiological Review 38.

[29] Hamad, Ibnu. KomunikasiUntukKehidupan, "Pengantar," dalam Brent D. Ruben dan Lea P. Stewart, KomunikasidanPerilakuManusia. Jakarta: RajawaliPers, 2013.

[30] Hamka, Rusdi. Islam dan Era Informasi.Bandung.

[31] Harahap, Syahrin. MetodologiStudiTokohPemikiran Islam. Medan: IstiqomahMulya, 2006.

[32] . Islam KonsepdanImplementasiPemberdayaan, Yogyakarta: Tiara Wacana, 1999.

[33] Hanson, C.W. Research User`s Needs: Users.Aslib Processing, No. 16.Februari 1964.

[34] Hasjmy, A. DusturDakwahMenurutAlqur`an. Jakarta: BulanBintang, 1974.

[35] Iskandar, MetodePenelitianKualitatif. Jakarta: GaungPersada, 2009.

[36] Kartono, Kartini. PsikologiSosialdanManajemenIndustri. Jakarta: Rajawali, 1988.

[37] Kasman, Suf. Jurnalisme Universal MenelusuriPrinsip-PrinsipDakwah bi al-QalamdalamAlquran. Jakarta: Teraju, 2004.

[38] Liliweri, Alo. MemahamiPeranKomunikasi Massa dalamMasyarakat. Bandung: Aditya, 1991.

[39] Littlejohn, S. W. Theories of Human Communication. California: Wadsworth Publishing Company, 1989.

[40] Mangindaan, Christina (dkk). PerilakuInformasiDosen (LaporanPenelitian). Jakarta: UI, 1993.

[41] Masy`ari, Anwar.Butir-butirProblematikaDakwah Islam. Banjarmasin: Binallmu, 1992.

[42] Meinanda, Teguh. PengantarIlmuKomunikasi. Bandung: Armico, 1987.

[43] Moeleong, Lexy J. MetodePenelitianKualitatif, Bandung: Rosdakarya, 2000. 
[44] Muhammad, Arni. KomunikasiOrganisasi.Jakarta: BumiAksara, 2002.

[45] Mulyana, Dedy. KomunikasiEfektif. Bandung: RemajaRosdakarya, 2004

[46] Muis, A.KomunikasiIslami. Bandung: RemajaRosdakarya, 2001.

[47] Nangtjik, Hasyim. ArtidanKonsepKebebasan Pers. DalamPersuratkabaran Indonesia dalam Era Informasi.SinarHarapan: 1986.

[48] Nadler, D.A.J.R. Hackman,\& E.E. Lawler, Organizational Behavior. Boston: Brown and Company, 1979.

[49] Notoatmodjo, Sukidjo. MetodologiPendidikandanPengajaran, Jakarta: BPKM FKMUI, 1980.

[50] Nurudin, Komunikasi Massa. Yogyakarta: Cespur, 2004.Oetama, Jacob. Persuratkabaran Indonesia dalam Era Reformasi. Jakarta: SinarHarapan, 1986.

[51] Effendi, OnongUchjana.IlmuKomunikasiTeoridanPraktek. Bandung: Rosdakarya, 1999.Pauline A. Handbook for Information System and Service. Paris: Unesco, 1977.

[52] Pendit,PutuLaxman.PenelitianIlmuPerpustakaandanInformasi:

SuatuPengantarDiskusiEfistimologidanMetodologi. Jakarta: JIP FSUI, 2003.

MaknaInformasi: PotensidanTantangan. Jakarta: Kasainc Blanc, 1992.Philip G.

Zimbardo\& Floyd L.Ruch, Psychology and Life. London: Diamond Printing, 1977.

[54] PusatPembinaandanPengembanganBahasa.EjaandalamBahasa Indonesia. Jakarta: Depdikbud, 1992.

[55] PusatPembinaandanPengembanganBahasa, PedomaUmumEjaanBahasa Indonesia yang Disempurnakan. Bandung: PustakaSetia, 1996.

[56] Putro, Santoso S. KomunikasiInternasionalSaranaInteraksiantarBangsa. Bandung: Alumni, 1984.

[57] Rachmadi, F. PerbandinganSistem Pers. Jakarta: Gramedia, 1990.

[58] Rakhmat, Jalaluddin. PsikologiKomunikasi. Bandung: Rosdakarya, 1994.

[59] Rakhmat, Jalaluddin. Islam Aktual. Bandung: Mizan, 1991.

[60] Robbins, Stephen P. PerilakuOrganisasi.Prentice-Hall, 2003.

[61] Rousydiy,T.A.Lathief. Dasar-DasarRethorika, Komunikasi, danInformasi. Medan: Rimbow,1989.

[62] Sendjaja, SasaDjuarsa. PengantarKomunikasi. Jakarta: Universitas Terbuka, 2005.

[63] . TeoriKomunikasi. Jakarta: Universitas Terbuka, 2005.

[64] Siagian, Sondang P. Organisasi, Kepemimpinan\&PerilakuAdministrasi. Jakarta: GunungAgung, 1997.

[65] Sophian, AinurRafiq.Tantangan Media Informasi Islam, Surabaya: RisalahGusti, 1993.

[66] Sugiyono, MetodePenelitianKuantitatifdanKualitatif.Bandung: Alfabeta, 2010.

[67] Sumadiria, A.S. Haris. SosiologiKomunikasi Massa. Bandung: Rekatama Media, 2014.

[68] Suprihanto, dkk.PerilakuOrganisasi. Yogyakarta: STIE YKPN, 2003.

[69] Susanto, Astrid S. KomunikasidalamTeoridanPraktek. Jakarta: Binacipta, 1977.

[70] Sutanta, Edhy.SistemInformasiManajemen. Yogyakarta: Grahallmu, 2003.

[71] Sutarto, Dasar-DasarOrganisasi. Yogyakarta: UGM Press, 1984.

[72] Spradley, J.P, Participant Observation. New York: Rinehart and Winston, 1980.

[73] S.W, Littlejohn Theories of Human Communication.Calitornia: Wadsworth Publishing Company, 1989.

[74] Terry, George R. Office Management and Control. Illinois: Homewood, 1962.

[75] T.D. Wilson, T.D. "Human Information Behaviour", dalamJurnal Informing Science Vol. 3 No.2, tahun 2000.

[76] Thoha, Miftah. PerilakuOrganisasiKonsepDasardanAplikasinya. Jakarta: Raja Grafindo, 2008.

[77] Trimo, Soejono. Dari DokumentasikeSistemInformasiManagemen. Bandung: RemajaKarya, 1987.

[78] Turner, Bryan S. Sosiologis Islam, AnalisisThesaSosiologi Webber. Jakarta: Rajawali, 1984.

[79] Wahjosumidjo, KepemimpinandanMotivasi. Jakarta: Ghalia, 1984.

[80] Widodo.TeknikWartawanMenulisBerita di SuratKabardanMajalah. Surabaya: Indah, 1997.

[81] WijayantiLucky.PerilakuPencarianInformasiStafPengajarFakultasSastra dalamMelakukanPenelitian.Depok: PPFSUI, 2001.

[82] Wursanto, Ig. Dasar-dasarIlmuOrganisasi. Yogyakarta: Andi Offset, 2005.

[83] Yulianah, KebutuhanInformasiPemustaka: StudiKasus di PerpustakaanKeliling Kota Administrasi. Depok: FIB, 2009.

[84] Yusuf, Pawit M \&PriyoSubekti.TeoridanPraktikPenelusuraInformasi, Jakarta: Kencana, 2010.

[85] . IlmuInformasi, KomunikasidanKepustakaan. Jakarta: BumiAksara, 2013.

[86] . PedomanMencariSumberInformasi. Bandung: RemajaRosdakarya, 1995.

[87] Young, Heartsill.Glossary of Information Science. Chicago: ALA, 1983.

[88] Zulkarnain, Wildan. DinamikaKelompok. Jakarta: BumiAksara, 2013.

Journal/Megazines: 
[89] Abdullah, Aslam. Media Muslim: SekarangdanMasaDepan. JurnalKomunikasi.Kuhlthau, Carol C. "Inside the Searching Process: Information Seeking from the User's Perspective", Journal of the American Society for Information Science 42, no. 361-371 Mei 1993.

[90] Sendjaja, SasaDjuarsa. "ParadigmaBaruPendidikanIlmuKomunikasi di Indonesia", dalamKomunika Vol. 8 No. $1 / 2005$

[91] Van Lunenburg, a Content Newspaper Analysis of Dutch Industry, Corporate Communication: An International Journal, 2000. Vol. 7, (2)

[92] RidwanSaidi, "Butir-ButirAkhirRenunganSoejatmoko," dalamPanjiMasyarakat (Pebruari 1990).

Newspapers:

[93] HarianAnalisa, "Berita: PersProfesi yang MenuntutIntlektualitas”Sabtu, (19 Desember 2015).

[94] RidwanLubis, "Agama dalam Era Globalisasi", dalamharianWaspada.

[95] Sugiatmo, "Catatandari NTU Workshop,"dalamHarianAnalisa Medan, Rabu, (10 Desember 2014).

[96] QuraishShihab, "Dialog Ramadhan" di Metro TV, (14 Juni 2016). 